\title{
Nutrient transfers by leaching in a no-tillage system through soil treated with repeated pig slurry applications
}

\author{
Eduardo Girotto • Carlos Alberto Ceretta • Cledimar Rogério Lourenzi • \\ Felipe Lorensini · Tadeu Luis Tiecher • Renan Costa Beber Vieira • \\ Gustavo Trentin · Claudir José Basso • Alcione Miotto • Gustavo Brunetto
}

Received: 22 July 2012 / Accepted: 9 January 2013/Published online: 25 January 2013

(C) Springer Science+Business Media Dordrecht 2013

\begin{abstract}
Repeated pig slurry applications cause accumulation and leaching of soil nutrients and, subsequently, groundwater contamination. The purpose of this study was to evaluate ammonium $\left(\mathrm{NH}_{4}{ }^{+}-\mathrm{N}\right)$, nitrate $\left(\mathrm{NO}_{3}{ }^{-}-\mathrm{N}\right)$, phosphorus $(\mathrm{P})$ and potassium $(\mathrm{K})$ leaching in a sandy soil with a 5-year history of repeated pig slurry applications. The study was carried out in the experimental field of the Universidade Federal de Santa Maria (UFSM) (Federal University of Santa Maria), Santa Maria, Rio Grande do Sul, in the South of Brazil, from 2002 to 2007, in no-tillage system in a Typic Hapludalf soil. Slurry was applied at doses of 0, 20, 40 and $80 \mathrm{~m}^{3} \mathrm{ha}^{-1}$, which over the 5 years amounted to the addition of 594, 1,188 and 2,376 $\mathrm{kg} \mathrm{N}$ ha $^{-1}$; 508, 1,016 and 2,032 $\mathrm{kg} \mathrm{P} \mathrm{ha}^{-1}$ and 216, 432 and $864 \mathrm{~kg} \mathrm{~K} \mathrm{ha}^{-1}$,
\end{abstract}

E. Girotto $(\square)$

Instituto Federal de Educação, Ciência e Tecnologia do Rio Grande do Sul, Campus Ibirubá, Rua Erly de Almeida Lima, número 600, apto 201, Santa Maria,

RS Cep: 97105-120, Brazil

e-mail: girottosolos@gmail.com

C. A. Ceretta - C. R. Lourenzi - F. Lorensini •

T. L. Tiecher - A. Miotto

Department of Soil Science of the Universidade Federal de Santa Maria, C. P. 221, Santa Maria,

RS Cep: 97105-900, Brazil

R. C. B. Vieira

Department of Soil Science of the Universidade Federal do Rio Grande do Sul, Avenida Bento Gonçalves

2100 416, Porto Alegre, RS Cep: 9065000, Brazil respectively. Leachate solutions were collected throughout the period, prepared and then subjected to analysis of $\mathrm{NH}_{4}{ }^{+}-\mathrm{N}, \mathrm{NO}_{3}{ }^{-}-\mathrm{N}, \mathrm{P}$ and $\mathrm{K}$ available in the solution. Repeated applications of pig slurry in a notillage system in sandy soil led to the transfer of elements through the leachate solution according to the sequence: nitrate $>$ potassium $>$ ammonium $>$ phosphorus. The transfers of these elements were positively related to the increased volume of leachate solution over the years in addition to the nutrient amounts added by the pig slurry applied over the 60-month period.

Keywords Pig manure - Loss through leaching · Nitrogen $\cdot$ Phosphorus $\cdot$ Potassium

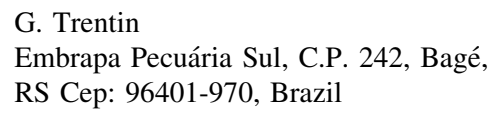

C. J. Basso

Department of Agronomy of the Universidade Federal de Santa Maria-CESNORS, Santa Maria, RS, Brazil

G. Brunetto

Department of Rural Engineering of the Universidade Federal de Santa Catarina, Rodovia Admar Gonzaga, 1346, Bairro Itacorubi, Florianopolis, SC Cep: 88034-000, Brazil 


\section{Introduction}

Pig slurry from swine production can be applied to the soil as a source of nutrients such as nitrogen $(\mathrm{N})$, phosphorus (P) and potassium (K), for annual crops and/or pasture. However, applications of increasing and continuous doses of pig slurry, which are not always established as based on defined technical criteria, can result in excessive accumulation of nutrients in the soil (Adeli et al. 2003; Ceretta et al. 2005; Bergström and Kirchmann 2006; Gatiboni et al. 2008; Adeli et al. 2008; Payet et al. 2009; Girotto et al. 2010; Ceretta et al. 2010a), which may enhance transfers of nutrients by surface runoff (Allen and Mallarino 2008; Ceretta et al. 2010b; Johnson et al. 2011) and also by leaching (Daudén et al. 2004; Bergström and Kirchmann 2006; Payet et al. 2009).

In pig slurry, most $\mathrm{N}$ is in the form of $\mathrm{NH}_{4}{ }^{+}-\mathrm{N}$ at the time of application on the soil, and in the soil, this is quickly transformed into $\mathrm{NO}_{3}{ }^{-}-\mathrm{N}$ (Diez et al. 2001; Aita et al. 2007; Payet et al. 2009). According to Aita et al. (2006), the nitrification rate for $\mathrm{N}$ applied through pig slurry to sandy soils with a history of application can reach $1.53 \mathrm{~kg} \mathrm{ha}^{-1} \mathrm{day}^{-1}$ in the first few days after application of pig slurry on the soil surface. Such rapid nitrification increases $\mathrm{NO}_{3}{ }^{-}-\mathrm{N}$ concentration in the soil (Loria and Sawyer 2005) and, if not taken up by plants, it may be transferred into the soil profile by the leachate solution (Basso et al. 2005; Bergström and Kirchmann 2006; Payet et al. 2009) as it forms an outer-sphere complex with the soil surface functional groups, which decreases the adsorption energy of the ion with the reactive organic and inorganic particles of the soil (Malhi et al. 2004).

For $\mathrm{P}, 60 \%$ is in inorganic forms in pig slurry (Cassol et al. 2001), with these forms predominantly being accumulated in soils with a history of pig manure application (Chardon et al. 2007; Hooda et al. 2001; Laboski and Lamb 2003; Gatiboni et al. 2008; Ceretta et al. 2010b). However, part of the P derived from slurry tends to be adsorbed on the most avid sites of reactive soil particle and the remainder may be retained in fractions with lower binding energy (Barrow et al. 1998) which increases its bioavailability and, consequently, its transfer rates through leaching (Sharpley et al. 1994; Pautler and Sims 2000; Smith et al. 2001; Ajmone-Marsan et al. 2006; Gatiboni et al. 2007).
The $\mathrm{K}$ present in pig slurry is usually found completely in mineral form (Kayser and Isselstein 2005). Normally, the amount of $\mathrm{K}$ found in pig slurry is less than the amounts of $\mathrm{N}$ and $\mathrm{P}$, and, coupled with the high demand for and export of the nutrient through crops (Ceretta et al. 2003; Lloveras et al. 2004), the amounts of $\mathrm{K}$ transferred by the leachate solution in areas with repeated applications of pig slurry are believed to be small.

$\mathrm{N}$ and $\mathrm{P}$ leaching in the soil profile, especially in sandy soils, can increase their levels in surface and underground waters, with $\mathrm{NO}_{3}{ }^{-}-\mathrm{N}$ concentrations above $10 \mathrm{mg} \mathrm{L}^{-1}$ and total $\mathrm{P}$ concentrations above $0.1 \mathrm{mg} \mathrm{L}^{-1}$, considered to be restricted levels for human consumption, as established by the Brazilian National Environmental Council (CONAMA 2005).

The purpose of this study was to assess $\mathrm{NH}_{4}{ }^{+}-\mathrm{N}$, $\mathrm{NO}_{3}{ }^{-}-\mathrm{N}, \mathrm{P}$ and $\mathrm{K}$ leaching in a sandy soil with a 5-year history of repeated pig slurry applications.

\section{Materials and methods}

Site description, treatment and evaluations

The experiment was carried out in the experimental field of the Universidade Federal de Santa Maria (RS) [Federal University of Santa Maria], in the South of Brazil (Latitude S $29^{\circ} 43^{\prime}$; Longitude W $53^{\circ} 42^{\prime}$ ), in a Typic Hapludalf soil (Soil Survey Staff 2006), in a sandy loam surface texture and a $4 \%$ slope. For 8 years, the area was kept in a no-tillage system, until the year 2000, when the experiment began. In March 2000, soil samples were taken in the $0-10 \mathrm{~cm}$ layer. The assessments presented in this study were conducted from 2002 to 2007. The results of the analyses were: clay $170 \mathrm{~g} \mathrm{~kg}^{-1}$, silt $300 \mathrm{~g} \mathrm{~kg}^{-1}$, sand $530 \mathrm{~g} \mathrm{~kg}^{-1}$, soil density $1.57 \mathrm{~g} \mathrm{~cm}^{-3}, \mathrm{pH}$ in water 4.7 , soil organic matter $16 \mathrm{~g} \mathrm{dm}^{-3}$, Al $0.8 \mathrm{cmol}_{\mathrm{c}} \mathrm{dm}^{-3}$ (extracted by $\mathrm{KCl} 1 \mathrm{~mol} \mathrm{~L}^{-1}$ ), $\mathrm{Ca} 2.7 \mathrm{cmol}_{\mathrm{c}} \mathrm{dm}^{-3}$ (extracted by $\mathrm{KCl}$ $1 \mathrm{~mol} \mathrm{~L}^{-1}$ ), $\mathrm{Mg} 1.1 \mathrm{cmol}_{\mathrm{c}} \mathrm{dm}^{-3}$ (extracted by $\mathrm{KCl}$ $1 \mathrm{~mol} \mathrm{~L}^{-1}$ ), P (extracted by Mehlich 1) $15.0 \mathrm{mg} \mathrm{dm}^{-3}$ and $96 \mathrm{mg} \mathrm{dm}^{-3}$ of $\mathrm{K}$ (extracted by Mehlich 1 ).

As of May 2002, the experimental field was managed under the following crop sequence: black-oats (Avena strigosa Schreb.), pearl millet (Pennisetum americanum L.) and black beans (Phaseolus vulgaris L.) in 2002; black-oats/common vetch (Vicia sativa L.) and maize in 2002/2003 and 2003/2004; black-oats, black 
Table 1 Applied pig slurry characteristics before the sowing of each culture in the sequence

\begin{tabular}{|c|c|c|c|c|c|c|c|c|c|c|c|c|}
\hline \multirow{3}{*}{$\begin{array}{l}\text { Pig Slurry } \\
\text { characteristics }\end{array}$} & \multicolumn{12}{|c|}{ Nutrient applied before each culture } \\
\hline & \multicolumn{12}{|c|}{ Third agricultural year $(2002 / 2003)$} \\
\hline & \multicolumn{4}{|c|}{ Black oat } & \multicolumn{4}{|l|}{ Maize } & \multicolumn{4}{|c|}{ Black bean } \\
\hline \multirow[t]{3}{*}{ Dry matter $\%$} & \multicolumn{4}{|l|}{0.47} & \multicolumn{4}{|l|}{6.68} & \multicolumn{4}{|l|}{4.82} \\
\hline & \multicolumn{4}{|c|}{ Application $-\mathrm{kg} \mathrm{ha}^{-1}$} & \multicolumn{4}{|c|}{ Application $-\mathrm{kg} \mathrm{ha}^{-1}$} & \multicolumn{4}{|c|}{ Application $-\mathrm{kg} \mathrm{ha}^{-1}$} \\
\hline & $\%$ & 20 & 40 & 80 & $\%$ & 20 & 40 & 80 & $\%$ & 20 & 40 & 80 \\
\hline Total-N $\mathrm{N}^{\mathrm{a}}$ & 0.11 & 22.0 & 44.0 & 88.0 & 0.75 & 150.0 & 300.0 & 600.0 & 0.22 & 44.0 & 88.0 & 176.0 \\
\hline Total phosphorus ${ }^{\mathrm{b}}$ & 2.12 & 2.0 & 4.0 & 8.0 & 1.19 & 15.9 & 31.8 & 63.6 & 2.95 & 28.4 & 56.8 & 113.6 \\
\hline \multirow[t]{3}{*}{ Total potassium ${ }^{\mathrm{b}}$} & 0.41 & 0.4 & 0.8 & 1.6 & 0.72 & 9.6 & 19.2 & 38.5 & 1.50 & 14.5 & 28.9 & 57.8 \\
\hline & \multicolumn{12}{|c|}{ Fourth agricultural year (2003/2004) } \\
\hline & \multicolumn{6}{|c|}{ Black oat + Common Vetch } & \multicolumn{6}{|c|}{ Maize } \\
\hline \multirow[t]{3}{*}{ Dry matter $\%$} & \multicolumn{6}{|l|}{2.37} & \multicolumn{6}{|l|}{2.07} \\
\hline & \multicolumn{6}{|c|}{ Application— $\mathrm{kg} \mathrm{ha}^{-1}$} & \multicolumn{6}{|c|}{ Application- $-\mathrm{kg} \mathrm{ha}^{-1}$} \\
\hline & \multicolumn{2}{|l|}{$\%$} & 20 & 40 & & 80 & $\%$ & & & 40 & & 80 \\
\hline Total- $\mathrm{N}^{\mathrm{a}}$ & 0.28 & & 6.0 & 112.0 & & 224.0 & 0.40 & & & 160.0 & & 320.0 \\
\hline Total phosphorus ${ }^{\mathrm{b}}$ & 3.41 & & 6.2 & 32.3 & & 64.6 & 3.33 & & & 27.6 & & 55.2 \\
\hline Total potassium ${ }^{\mathrm{b}}$ & 2.90 & & 3.7 & 27.5 & & 55.0 & 4.58 & & & 38.0 & & 76.0 \\
\hline & Fifth & cultura & year $(2004$ & & & & & & & & & \\
\hline & Black & $+\mathrm{Co}$ & mon Vetch & & & & Maiz & & & & & \\
\hline Dry matter $\%$ & 1.0 & & & & & & 7.2 & & & & & \\
\hline & Applic & on- $\mathrm{kg}$ & $\mathrm{aa}^{-1}$ & & & & Appl & ion- $\mathrm{kg}$ & & & & \\
\hline & $\%$ & & 20 & 40 & & 80 & $\%$ & & & 40 & & 80 \\
\hline $\mathrm{N}-$ total $^{\mathrm{a}}$ & 0.06 & & 12.0 & 24.0 & & 48.0 & 0.37 & & & 148.0 & & 296.0 \\
\hline Total phosphorus ${ }^{\mathrm{b}}$ & 4.22 & & 8.4 & 16.8 & & 33.6 & 5.58 & & & 160.6 & & 321.2 \\
\hline Total potassium ${ }^{\mathrm{b}}$ & 10.13 & & 20.3 & 40.5 & & 81.0 & 1.27 & & & 36.6 & & 73.2 \\
\hline & Sixth & icultur & year $(2005$ & & & & & & & & & \\
\hline & Black & & & & Black & bean & & & Sunnh & & & \\
\hline Dry matter $\%$ & 6.8 & & & & 8.9 & & & & 12.14 & & & \\
\hline & Applic & $\mathrm{n}-\mathrm{kg}$ & $a^{-1}$ & & Appli & cation $-\mathrm{kg}$ & & & Applic & $\mathrm{n}-\mathrm{kg} \mathrm{l}$ & & \\
\hline & $\%$ & 20 & 40 & 80 & $\%$ & 20 & 40 & 80 & $\%$ & 20 & 40 & 80 \\
\hline N-total ${ }^{\mathrm{a}}$ & 0.30 & 60.0 & 120.0 & 240 & 0.12 & 24.0 & 48.0 & 96.0 & 0.10 & 20.0 & 40.0 & 80.0 \\
\hline Total phosphorus ${ }^{\mathrm{b}}$ & 2.95 & 40.1 & 80.2 & 160.4 & 4.43 & 60.2 & 120.5 & 241.0 & 4.79 & 116.3 & 232.6 & 465.2 \\
\hline Total potassium ${ }^{\mathrm{b}}$ & 0.91 & 12.4 & 24.8 & 49.6 & 2.44 & 33.2 & 66.4 & 132.8 & 1.01 & 24.5 & 49.0 & 98.0 \\
\hline & Sevent & gricult & al year $(20$ & 2007) & & & & & & & & \\
\hline & Black & & & & & & & & & & & \\
\hline Dry matter $\%$ & 9.94 & & & & & & 1. & & & & & \\
\hline & Applica & - $\mathrm{kg}$ & & & & & & cation- & $\mathrm{ha}^{-1}$ & & & \\
\hline & $\%$ & & 0 & 40 & & 80 & $\%$ & & 20 & & & 80 \\
\hline
\end{tabular}


Table 1 continued

\begin{tabular}{|c|c|c|c|c|c|c|c|c|}
\hline & \multicolumn{4}{|c|}{ Application- $\mathrm{kg} \mathrm{ha}^{-1}$} & \multicolumn{4}{|c|}{ Application $-\mathrm{kg} \mathrm{ha}^{-1}$} \\
\hline & $\%$ & 20 & 40 & 80 & $\%$ & 20 & 40 & 80 \\
\hline $\mathrm{N}$-total ${ }^{\mathrm{a}}$ & 0.10 & 20.0 & 40.0 & 80.0 & 0.16 & 32.0 & 64.0 & 128.0 \\
\hline Total phosphorus ${ }^{b}$ & 5.37 & 106.7 & 213.5 & 427.0 & 5.18 & 19.8 & 39.6 & 79.2 \\
\hline Total potassium $^{\mathrm{b}}$ & 1.85 & 36.8 & 73.6 & 147.2 & 3.56 & 13.6 & 27.2 & 54.4 \\
\hline
\end{tabular}

a Analyses and calculations on a humid weight base

b Analyses and calculations on a dry weight base

beans and sunn hemp (Crotalaria juncea L.) in 2005/2006 and, finally, black-oats and maize in $2006 / 2007$. Maize and black beans are grown in the spring and summer as cash crops. In addition, common vetch and black-oats are grown in the winter, and sunn hemp and pearl millet are grown in the spring, as cover crops. All the stubble produced was left on the soil surface.

First, pig slurry doses of $0,20,40$ and $80 \mathrm{~m}^{3} \mathrm{ha}^{-1}$ were applied on a total area of $12 \mathrm{~m}^{2}(4 \mathrm{~m} \times 3 \mathrm{~m})$ in May 2000. A randomized block experimental design with four replicates was used. Annual pig slurry applications and crops are shown in Table 1. After grain harvest in summer crops, or flowering in winter crops, plants were desiccated and, on the crop residues, pig slurry was applied for the next crop. Pig slurry was spread on the soil surface 1 day before the sowing of each crop, without incorporating it into the soil. Over the 2002-2007 period, twelve pig slurry applications were performed. Added to the six applications applied before 2002, as of the year 2000, this results in eighteen pig slurry applications.

In March 2000, two lysimeters were installed in each plot at a depth of $0.60 \mathrm{~m}$, with $0.40 \mathrm{~m}$ width and $0.60 \mathrm{~m}$ length, built with a $4 \mathrm{~mm}$ thick polyvinyl chloride (PVC) plate. Each leachate solution collector was connected to a 5-L capacity storage container (Fig. 1). Washed gravel with an $\mathrm{HCl} 0.1 \mathrm{~mol} \mathrm{~L}^{-1}$ solution was placed inside each lysimeter and, over the gravel, a sheet of filter material (Bidim). Removal of leached water from the collector was performed by suction, using a vacuum pump after each event (rainfall + leaching), from April 2002 to April 2007. After each rainfall and sufficient leached volume for analysis, the stored leached volume was removed from the collectors, its volume was measured, and a sample $(300 \mathrm{ml})$ was taken to the laboratory for analysis.

Nutrient analysis

Ammonium and nitrate concentrations were determined using unfiltered samples of leaching; $20 \mathrm{~mL}$ of the sample collected in the field was distilled and then $0.2 \mathrm{~g}$ of $\mathrm{MgO}$ was added to it. The ammonium concentration $\left(\mathrm{NH}_{4}{ }^{+}-\mathrm{N}\right)$ was determined in a Kjeldahl half-micron vapor distiller, the distilled material being collected in boric acid and the extract entitlement carried out with diluted $\mathrm{H}_{2} \mathrm{SO}_{4}$ (Tedesco et al. 1995). In another sample, $0.2 \mathrm{~g}$ of Devarda's alloy was added for determination of $\mathrm{NO}_{3}{ }^{-}-\mathrm{N}$ concentration (Tedesco et al. 1995).
Fig. 1 Lysimeter design (a) and layout for lysimeters installation (b) to collect the leachate solution from the soil
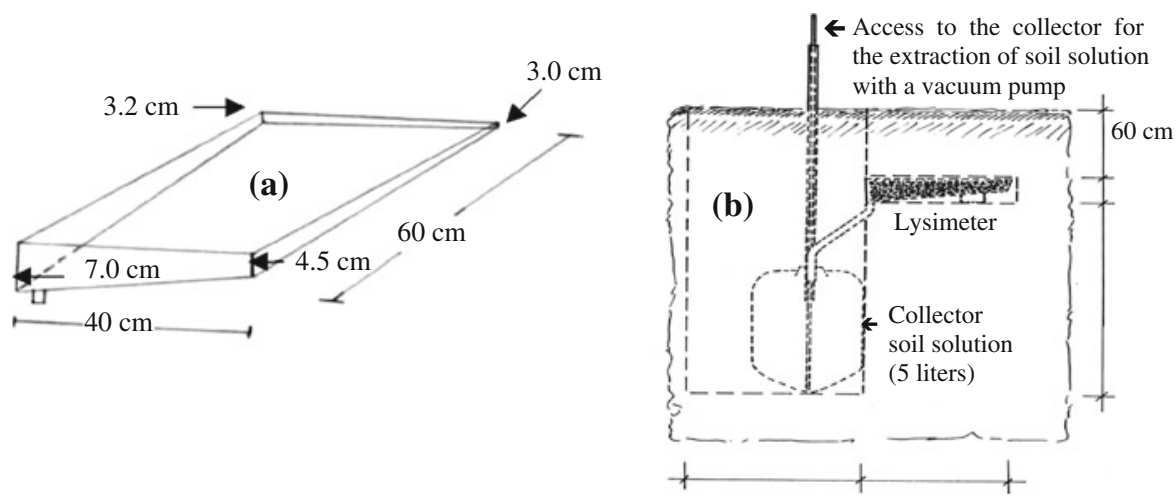
$\mathrm{P}$ and $\mathrm{K}$ concentrations were determined by using unfiltered leachate samples. $50 \mathrm{ml}$ solution samples collected from each experimental unit in the field, with material in suspension, were placed in $100 \mathrm{~mL}$ snap-cap bottles, and then $1 \mathrm{~mL}$ of $\mathrm{HCl} 0.11 \mathrm{~mol} \mathrm{~L}^{-1}$ (PA) (extracting solution) was added to it. Samples were intermittently agitated for $10 \mathrm{~min}$ and subsequently left to rest for $16 \mathrm{~h}$. Afterwards, $5 \mathrm{~mL}$ of the extract were separated and phosphorus content was determined by the Murphy and Riley (1962) method and potassium content by flame spectrometry (B262 Micronal).

For total $\mathrm{N}$ determination in pig slurry samples, the liquid and pasty fractions were separated. This procedure is necessary in order to calculate the proportions of both sample fractions to be weighed so the $\mathrm{N}$ levels originally present in the pig slurry can be assessed, avoiding unrepresentative sampling. Approximately $50 \mathrm{~g}$ of pig slurry were centrifuged for $20 \mathrm{~min}$ at $1,500 \mathrm{~g}$, resulting in two fractions. Then, $0.2 \mathrm{~g}$ of the pasty fraction were collected in a $50 \mathrm{~mL}$ capacity digestion tube and a proportional amount of liquid added to it, thus reconstituting the two fractions originally present in the pig slurry. Afterwards, $2 \mathrm{~mL}$ of concentrated sulfuric acid, $2 \mathrm{~mL}$ of $30 \%$ hydrogen peroxide, and $0.7 \mathrm{~g}$ of a digestion mixture $\left(\mathrm{Na}_{2} \mathrm{SO}_{4}+\mathrm{CuSO}_{4} \cdot 5 \mathrm{H}_{2} \mathrm{O}\right)$ were added to it (Tedesco et al. 1995). Then, $10 \mathrm{~mL}$ of the sample was distilled in a Kjeldahl half-micron vapor drag distiller, with the addition of $5 \mathrm{~mL}$ of $\mathrm{NaOH} 10 \mathrm{~N}$. The distilled fraction was collected in boric acid indicator solution and titrated with $\mathrm{H}_{2} \mathrm{SO}_{4} 0.05 \mathrm{~N}$.

For total $\mathrm{P}$ and $\mathrm{K}$ analysis, the pig slurry was dried in a laboratory drying oven with air temperature at $65{ }^{\circ} \mathrm{C}$ until constant weight was obtained. Afterwards, $0.2 \mathrm{~g}$ of dried pig slurry was separated and placed in a $50-\mathrm{mL}$ distillation tube with $2 \mathrm{~mL}$ of concentrated sulfuric acid, $1 \mathrm{~mL}$ of $30 \%$ hydrogen peroxide and $0.7 \mathrm{~g}$ of a digestion mixture $\left(\mathrm{Na}_{2} \mathrm{SO}_{4}+\mathrm{CuSO}_{4}\right.$. $5 \mathrm{H}_{2} \mathrm{O}$ ) (Tedesco et al. 1995). At the end of the digestion process, $\mathrm{P}$ content was determined by the Murphy and Riley (1962) method and K by flame spectrometry (B262 Micronal). Dry matter content and the total N, P and $\mathrm{K}$ amounts applied via pig slurry are presented in Table 1.

The amount of $\mathrm{P}$ extracted by anion exchanging resins was determined in the pig slurry. The extraction process was carried out in $11 \mathrm{~mL}$ glass test tubes, using $0.2 \mathrm{~g}$ of pig slurry dry fraction, adding anionexchange resin in $2.5 \mathrm{~cm} \times 3.0 \mathrm{~cm}$ blades, saturated in bicarbonate (Cassol et al. 2001) and $10 \mathrm{~mL}$ of deionized water. The suspension was agitated for $16 \mathrm{~h}$ in an end-over-end agitator at $27 \mathrm{rpm}$. The $\mathrm{P}$ retained in the blades was recovered with $20 \mathrm{~mL}$ of $\mathrm{HCl}$ $0.5 \mathrm{~mol} \mathrm{~L}^{-1}$ and the $\mathrm{P}$ concentration was determined by the Murphy and Riley (1962) method in a $3 \mathrm{~mL}$ aliquot of the extract.

\section{Statistical treatment of data}

Analysis of variance (ANOVA) was performed to determine treatment effects on leaching and on ammonium, nitrate, $\mathrm{P}$ and $\mathrm{K}$ losses in leaching. Differences among treatment effects were determined using the Tukey-Kramer test. Mean values of the treatments were compared using the Least Square Difference (LSD) with a significance level of $p<0.05$. Linear regression analysis $(\mathrm{y}=\mathrm{a}+\mathrm{bx})$ was used to test the significance of time trends in ammonium loss $\left(\mathrm{NH}_{4}{ }^{+}\right.$loss $)$, nitrate loss $\left(\mathrm{NO}_{3}{ }^{-}\right.$loss $)$, available phosphorus loss (Ploss) and available potassium loss (Kloss) of slurry rate (SR), annual leaching (Leaching), cumulative leaching (Leaching cum) and cumulative nutrients added for multiple year (amount of nitrogen applied (Nadd), amount of phosphorus applied (Padd) and amount of potassium applied (Kadd)) at $p<0.05$. Pearson statistical tests were performed to check correlations between leaching and the losses of ammonium, nitrate, $\mathrm{P}$ and $\mathrm{K}$. All statistical analyses were performed using SISVAR (Ferreira 2008).

\section{Results and discussion}

Leaching volume and ammonium and nitrate losses

Solution volumes transferred by leaching to a depth greater than $0.60 \mathrm{~m}$ in a soil under the application of 0 , 20,40 and $80 \mathrm{~m}^{3} \mathrm{ha}^{-1}$ of pig slurry did not present a good correlation with the amount of rainfall (Fig. 2). The largest transfers of leachate solution were observed in the 2002/2003 crop season, when annual precipitation was $56 \%$ higher than the 5-year average rainfall (Table 2). In addition, in the soil with a history of application of $40 \mathrm{~m}^{3} \mathrm{ha}^{-1}$ pig slurry over the years, greater amounts of leachate solution were observed (Table 2). 
Fig. 2 Solution transfer through leaching in the following crops: black beans (2002/2003) (a), maize (2003/2004) (b), maize $(2004 / 2005)(\mathbf{c})$, black beans (2005/2006) (d) and maize $(2006 / 2007)$ (e), in areas under repeated pig slurry applications and no-tillage (bars standard errors).

Significance levels are based ANOVA testing system for differences between treatment means. Letters designate differences between treatments means, identified by Tukey-Kramer multiple comparison tests, while n.s. denotes statistical similarity amongst means

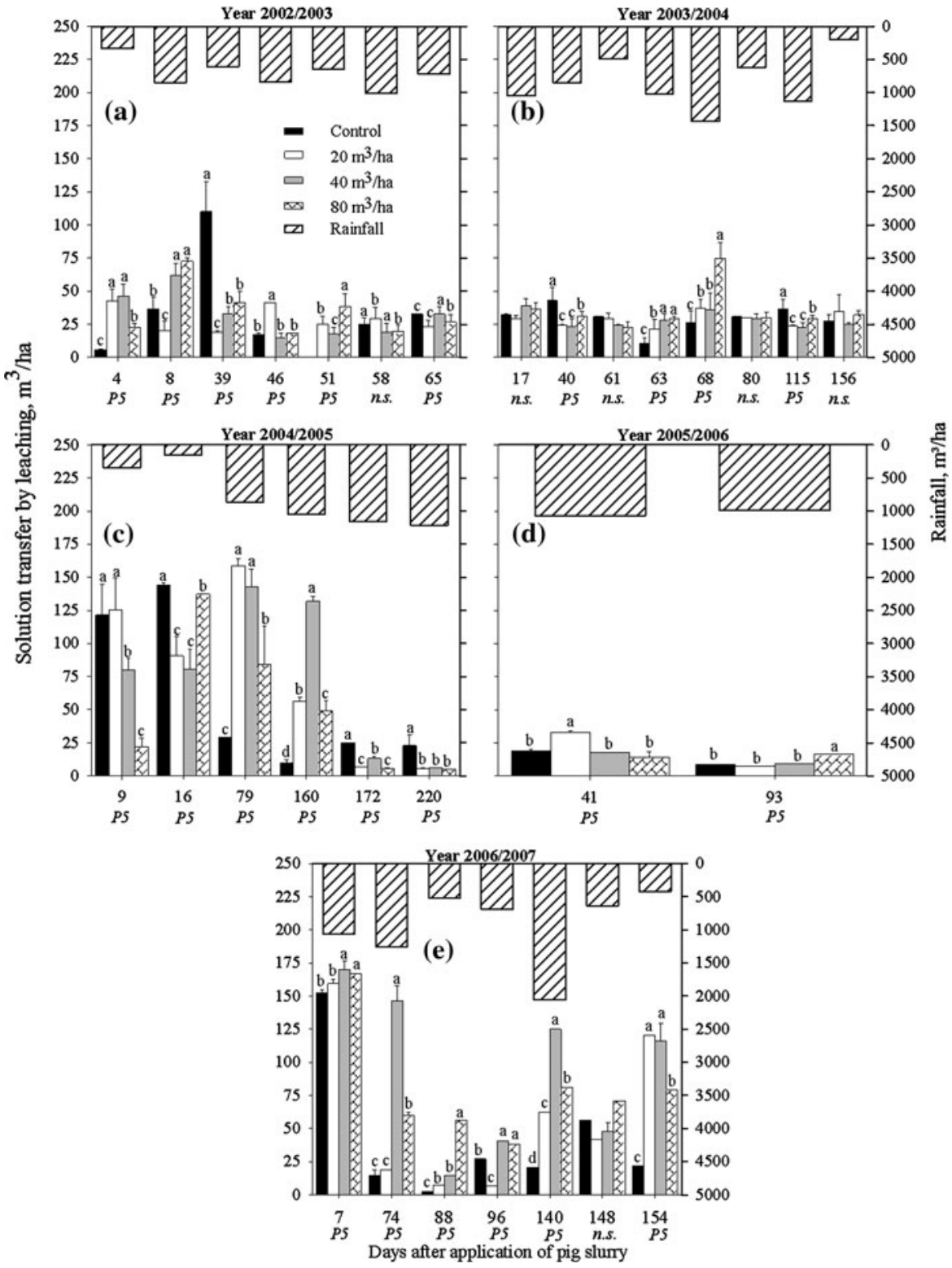

In joint assessment of all treatments, the application of $0,20,40$ and $80 \mathrm{~m}^{3} \mathrm{ha}^{-1}$ doses of pig slurry were not related to the leachate solution volume in any of the years analyzed (Table 3). However, in some events, especially in the first few days after slurry application, a lower leachate solution volume was found when applying $80 \mathrm{~m}^{3} \mathrm{ha}^{-1}$ of pig slurry, as observed at 4,9 and 41 days after the pig slurry application in the 2002/2003, 2004/2005 and 2005/2006 crop years, respectively (Fig. 2a, c, d). Such lower leachate solution volume can be ascribed to clogged pores in the soil surface layer by fine slurry particles, as reported by
Edwards and Daniel (1993) in a study on fescue grass that received the application of pig slurry doses equivalent to 0,217 and $435 \mathrm{~kg} \mathrm{~N}^{-1}$ and subjected to simulated rainfall intensities of 50 and $100 \mathrm{~mm} \mathrm{~h}^{-1}$, $24 \mathrm{~h}$ after slurry application.

The amount of water transferred by leaching was, on average, $1.63,1.87,3.16$ and $2.20 \%$ of the rainfall that occurred during the 5 years in which this study was carried out for the $0,20,40$ and $80 \mathrm{~m}^{3} \mathrm{ha}^{-1}$ doses, respectively. These results show the greater leaching levels where pig slurry was applied. That may be attributable to the lower volume transferred by runoff, 
Table 2 Amount of nutrients applied and lost through leaching for each pig slurry dose in the 2002/2003, 2003/2004, 2004/2005, 2005/2006 and 2006/2007 crops

\begin{tabular}{|c|c|c|c|c|c|c|c|c|c|}
\hline \multirow{2}{*}{$\begin{array}{l}\text { Pig slurry } \\
\text { rate } \\
\mathrm{m}^{3} \mathrm{ha}^{-1}\end{array}$} & \multicolumn{3}{|c|}{ Applied amount of nutrient } & \multirow{2}{*}{$\begin{array}{l}\text { Precipitation } \\
\left(\mathrm{m}^{3} \mathrm{ha}^{-1}\right. \\
\left.\text { year }^{-1}\right)\end{array}$} & \multirow{2}{*}{$\begin{array}{l}\text { Leaching } \\
\left(\mathrm{m}^{3} \mathrm{ha}^{-1}\right. \\
\left.\text { year }^{-1}\right)\end{array}$} & \multicolumn{4}{|c|}{ Nutrient losses } \\
\hline & $\begin{array}{l}\mathrm{N} \\
\left(\mathrm{kg} \mathrm{ha}^{-1}\right)\end{array}$ & $\begin{array}{l}\mathrm{P} \\
\left(\mathrm{kg} \mathrm{ha}^{-1}\right)\end{array}$ & $\begin{array}{l}\mathrm{K} \\
\left(\mathrm{kg} \mathrm{ha}^{-1}\right)\end{array}$ & & & $\begin{array}{l}\text { Ammonium } \\
\left(\mathrm{kg} \mathrm{ha}^{-1}\right)\end{array}$ & $\begin{array}{l}\text { Nitrate }^{\mathrm{c}} \\
\left(\mathrm{kg} \mathrm{ha}^{-1}\right)\end{array}$ & $\begin{array}{l}\text { Available } \\
\text { phosphorus }^{\mathrm{d}} \\
\left(\mathrm{kg} \mathrm{ha}^{-1}\right)\end{array}$ & $\begin{array}{l}\text { Available } \\
\text { potassium }^{\mathrm{e}} \\
\left(\mathrm{kg} \mathrm{ha}^{-1}\right)\end{array}$ \\
\hline
\end{tabular}

Agricultural year 2002/2003

$\begin{array}{rrrrr}00 & - & - & - & 25102 \\ 20 & 216 & 46 & 24 & 25102 \\ 40 & 432 & 93 & 49 & 25102 \\ 80 & 864 & 185 & 98 & 25102\end{array}$

Agricultural year 2003/2004

\begin{tabular}{|c|c|c|c|c|c|c|c|c|c|}
\hline 00 & - & - & - & 13983 & $135(0.96) \mathrm{c}$ & $0.04 \mathrm{~ns}$ & $0.37 \mathrm{c}$ & $0.03 \mathrm{c}$ & $0.19 \mathrm{c}$ \\
\hline 20 & 136 & 30 & 33 & 13983 & $222(1.59) \mathrm{b}$ & $0.07(0.03)$ & $1.94(1.50) \mathrm{b}$ & $0.07(0.13) \mathrm{b}$ & $0.31(0.37) b c$ \\
\hline 40 & 272 & 60 & 65 & 13983 & $331(2.37) \mathrm{a}$ & $0.06(0.01)$ & $2.51(1.04) \mathrm{b}$ & $0.05(0.03) b c$ & $0.51(0.49) \mathrm{b}$ \\
\hline 80 & 544 & 120 & 131 & 13983 & $264(1.89) \mathrm{ab}$ & $0.05(0.002)$ & $5.03(1.16) \mathrm{a}$ & $0.12(0.08) \mathrm{a}$ & $0.89(0.53) \mathrm{a}$ \\
\hline \multicolumn{10}{|c|}{ Agricultural year 2004/2005 } \\
\hline 00 & - & - & - & 11241 & $137(1.22) \mathrm{bc}$ & $0.19 \mathrm{ab}$ & $3.32 \mathrm{c}$ & $0.06 \mathrm{~ns}$ & $0.73 \mathrm{~ns}$ \\
\hline 20 & 86 & 89 & 39 & 11241 & $97(0.86) \mathrm{c}$ & $0.43(0.36) \mathrm{a}$ & $14.96(17.58) \mathrm{a}$ & $0.04(0.00)$ & $0.33(0.00)$ \\
\hline 40 & 172 & 177 & 77 & 11241 & $363(3.23) \mathrm{a}$ & $0.24(0.04) a b$ & $9.04(4.38) \mathrm{b}$ & $0.04(0.00)$ & $0.40(0.00)$ \\
\hline 80 & 344 & 355 & 154 & 11241 & $190(1.69) \mathrm{ab}$ & $0.05(0.00) \mathrm{b}$ & $2.56(0.00) \mathrm{c}$ & $0.07(0.008)$ & $0.29(0.00)$ \\
\hline \multicolumn{10}{|c|}{ Agricultural year 2005/2006 } \\
\hline 00 & - & - & - & 11427 & $278(2.43) \mathrm{ab}$ & $0.03 \mathrm{~ns}$ & $0.63 \mathrm{a}$ & $0.04 \mathrm{~ns}$ & $0.46 \mathrm{~ns}$ \\
\hline 20 & 104 & 217 & 70 & 11427 & $246(2.15) \mathrm{ab}$ & $0.07(0.05)$ & $0.62(0.00) \mathrm{a}$ & $0.04(0.00)$ & $0.75(0.41)$ \\
\hline 40 & 208 & 433 & 140 & 11427 & $348(3.04) \mathrm{a}$ & $0.01(0.00)$ & $0.28(0.00) \mathrm{b}$ & $0.05(0.002)$ & $0.38(0.00)$ \\
\hline 80 & 416 & 866 & 280 & 11427 & $211(1.85) \mathrm{b}$ & $0.01(0.00)$ & $0.44(0.00) \mathrm{ab}$ & $0.07(0.004)$ & $0.33(0.00)$ \\
\hline \multicolumn{10}{|c|}{ Agricultural year 2006/2007 } \\
\hline 00 & - & - & - & 18744 & $226(1.21) \mathrm{b}$ & $0.21 \mathrm{~ns}$ & $1.09 \mathrm{~d}$ & $0.03 \mathrm{~ns}$ & $0.17 \mathrm{~ns}$ \\
\hline 20 & 52 & 126 & 50 & 18744 & $190(1.01) \mathrm{b}$ & $0.28(0.17)$ & $2.82(4.32) \mathrm{c}$ & $0.08(0.04)$ & $0.47(0.60)$ \\
\hline 40 & 104 & 253 & 101 & 18744 & $487(2.60) \mathrm{a}$ & $0.24(0.04)$ & $8.01(8.76) \mathrm{a}$ & $0.13(0.04)$ & $0.74(0.56)$ \\
\hline 80 & 208 & 506 & 202 & 18744 & $176(0.94) b$ & $0.17(0.00)$ & $4.74(2.37) \mathrm{b}$ & $0.05(0.02)$ & $0.53(0.18)$ \\
\hline \multicolumn{10}{|c|}{ Average of 5 years } \\
\hline 00 & - & - & - & 16099 & $262(1.63)$ & 0.12 & 1.37 & 0.05 & 0.46 \\
\hline 20 & 119 & 102 & 43 & 16099 & $301(1.87)$ & $0.22(0.11)$ & $4.51(3.43)$ & $0.06(0.01)$ & $0.74(0.65)$ \\
\hline 40 & 238 & 203 & 87 & 16099 & $509(3.16)$ & $0.19(0.04)$ & $4.93(1.97)$ & $0.07(0.01)$ & $0.75(0.33)$ \\
\hline 80 & 475 & 406 & 173 & 16099 & $355(2.20)$ & $0.14(0.006)$ & $3.88(0.71)$ & $0.12(0.02)$ & $1.05(0.34)$ \\
\hline
\end{tabular}

${ }^{a}$ Significance levels are from ANOVA testing for differences between treatment means. Letters designate differences between treatment means identified by Tukey-Kramer multiple comparison tests in a column, while n.s. denotes statistical similarity amongst means

${ }^{b}$ Nitrogen transferred in the ammonium form

${ }^{\mathrm{c}}$ Nitrogen transferred in the nitrate form

${ }^{\mathrm{d}}$ Phosphorus extracted by $\mathrm{HCl} 0.11 \mathrm{~mol} \mathrm{~L}^{-1}$

e Potassium extracted by $\mathrm{HCl} 0.11 \mathrm{~mol} \mathrm{~L}^{-1}$

${ }^{\mathrm{f}}$ Numbers in parentheses represent the percentage of water losses by leaching in relation to rainfall in the period

$\mathrm{g}$ The numbers in parentheses represent the percentages of nutrient losses relatively to the total applied deducted of the amount of losses where manure was not applied, considering a potential of loss volatilization of the mineral $\mathrm{N}$ by volatilization of 23,24 and $26 \%$ for the rates of 20,40 and $80 \mathrm{~m}^{3} \mathrm{ha}^{-1}$ of pig slurry, respectively in accordance to Basso et al. (2004) and deducting the value of the losses where manure was not applied

${ }^{\mathrm{h}}$ The numbers in parentheses represent the percentage of losses in relation to the $\mathrm{P}$ and $\mathrm{K}$ applied via manure, deducting the value of the losses where pig slurry was not applied 


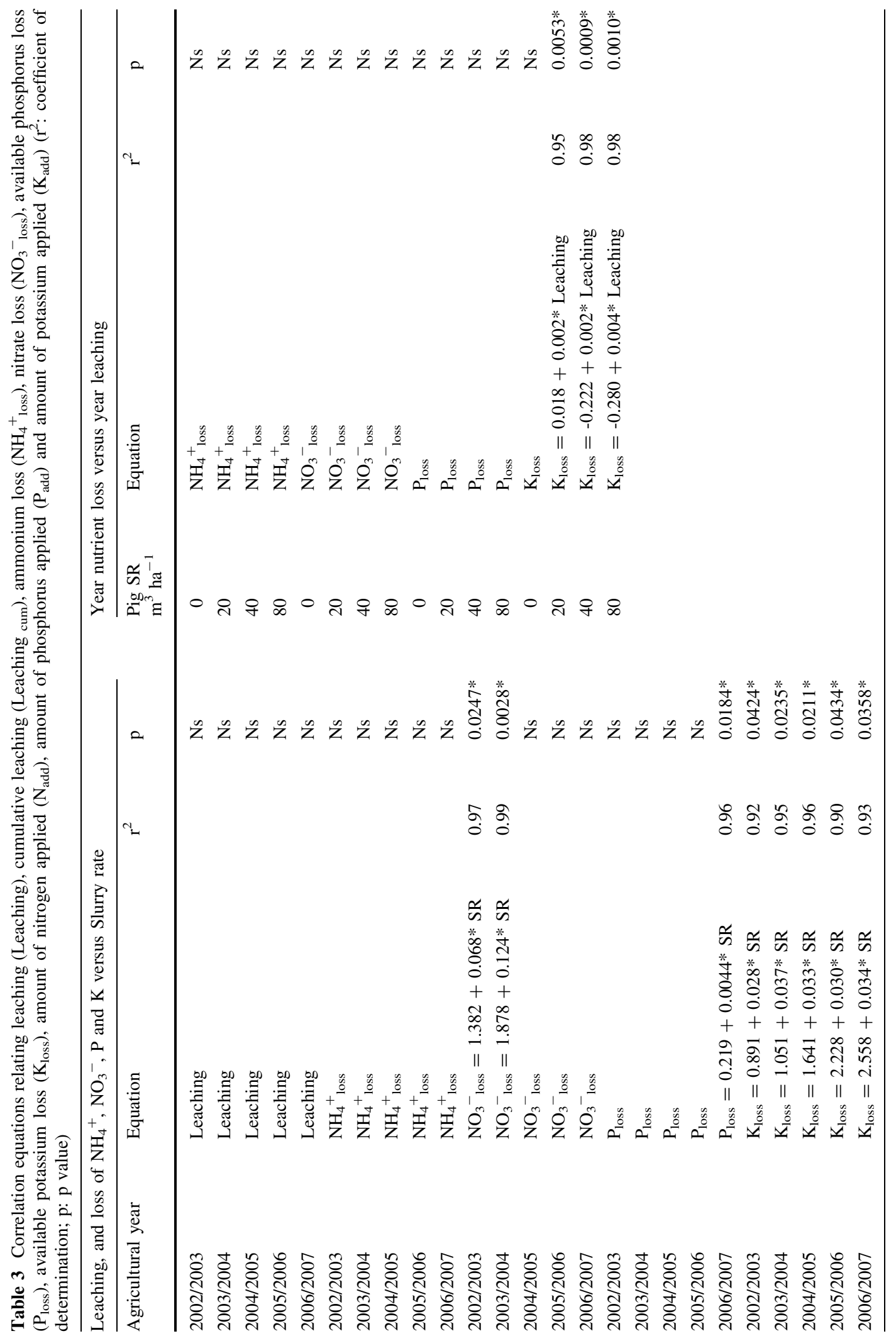




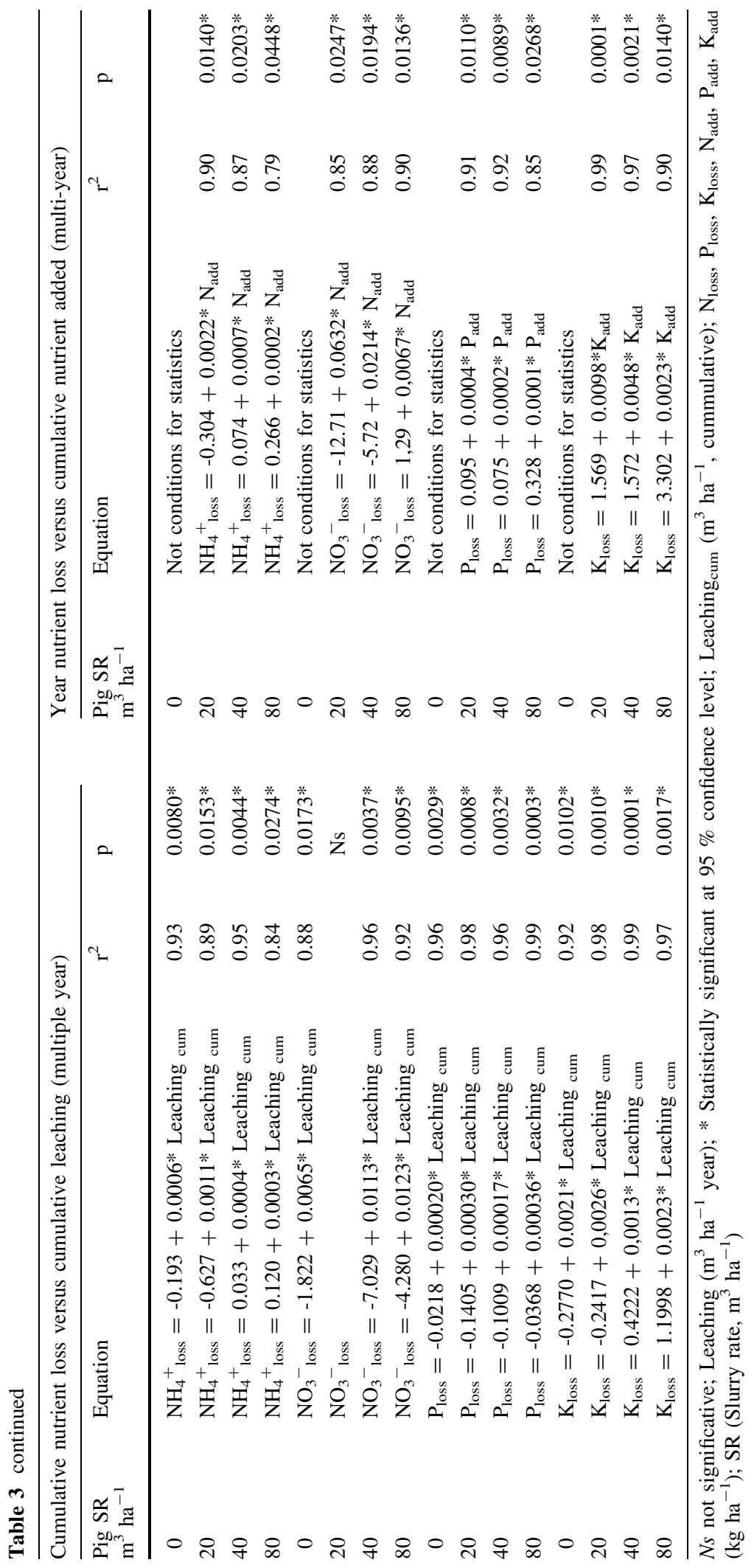


Fig. 3 Ammonium $\left(\mathrm{N}-\mathrm{NH}_{4}{ }^{+}\right)$transfer through leaching in the following crops: black beans (2002/ 2003) (a), maize (2003/ 2004) (b), maize (2004/ 2005) (c), black beans (2005/2006) (d) and maize $(2006 / 2007)(\mathbf{e})$, in areas under repeated pig slurry applications and no-tillage (bars standard errors).

Significance levels are based ANOVA testing system for differences between designate differences between treatments means, identified by Tukey-Kramer multiple comparison tests, while n.s. denotes statistical similarity amongst means treatment means. Letters
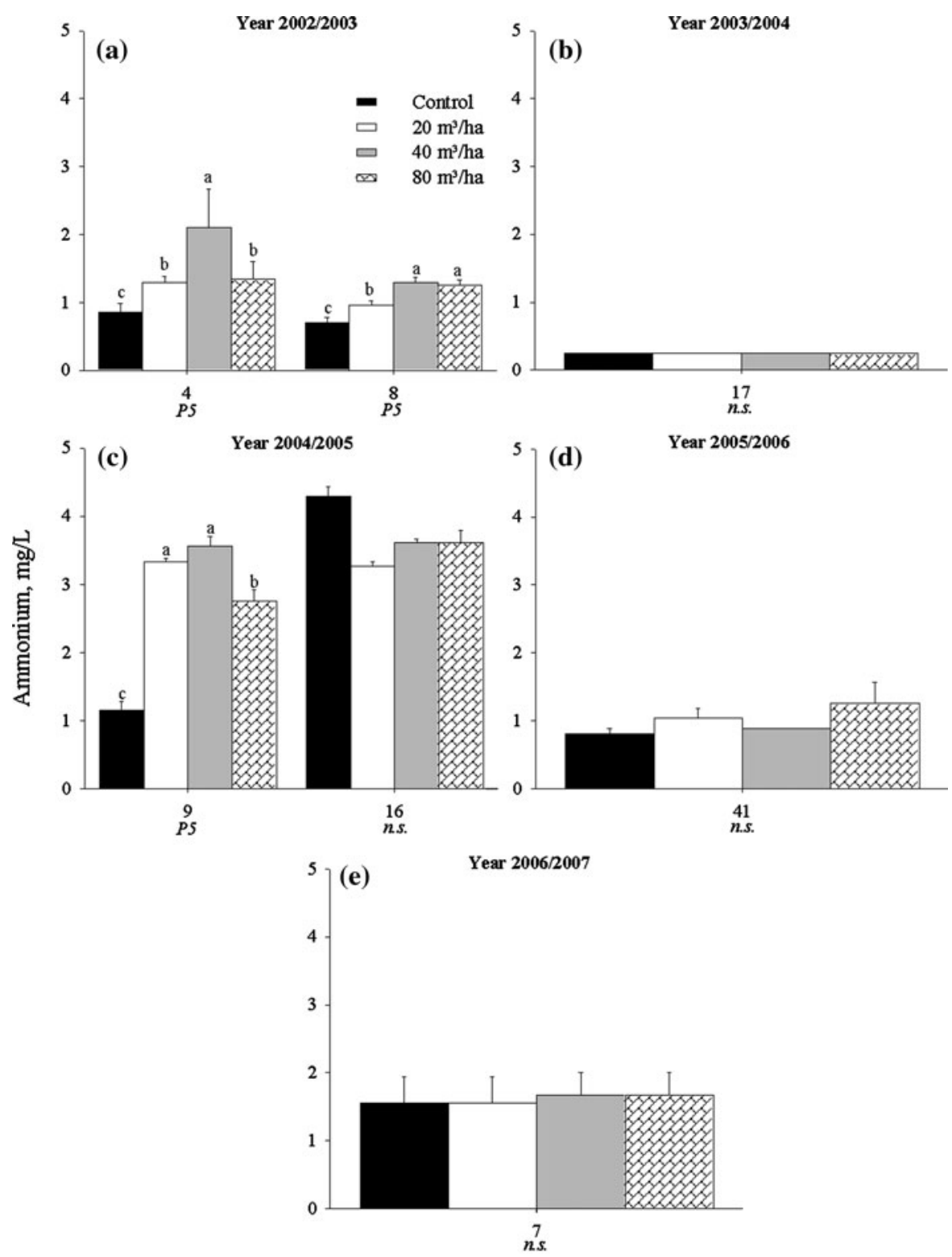

Days after application of pig slurry

as a result of increased production and disposition of crop dry matter on the soil surface, as noted by Ceretta et al. (2010b) in a study conducted in the same experiment as the subject of the present study. These results are also similar to those obtained by Logan et al. (1994), in an experiment set up in a no-tillage system in soil with a maize-soybean crop rotation in 1987 and 1988, when leachate solution transfers equivalent to 1.37 and $1.54 \%$ of total rainfall were observed. These same authors report that the transfers through leaching are irregular in relation to the rainfall volume since there may be torrents of rain with high water volume and low leachate volume.

From 2002 to $2007,594,1,188$ and 2,376 $\mathrm{kg} \mathrm{N}^{-1}$ were applied on the soil, with twelve 20,40 and $80 \mathrm{~m}^{3} \mathrm{ha}^{-1}$ pig slurry applications, respectively. However, part of that $\mathrm{N}$ may have been lost by ammonia volatilization since approximately $60 \%$ of $\mathrm{N}$ in pig slurry is found in the ammoniacal form (Aita et al. 2007; Payet et al. 2009). In a study carried out in the same experiment, Basso et al. (2004) found $\mathrm{N}$ losses by volatilization equivalent to 23,24 and $26 \%$ in the 20,40 


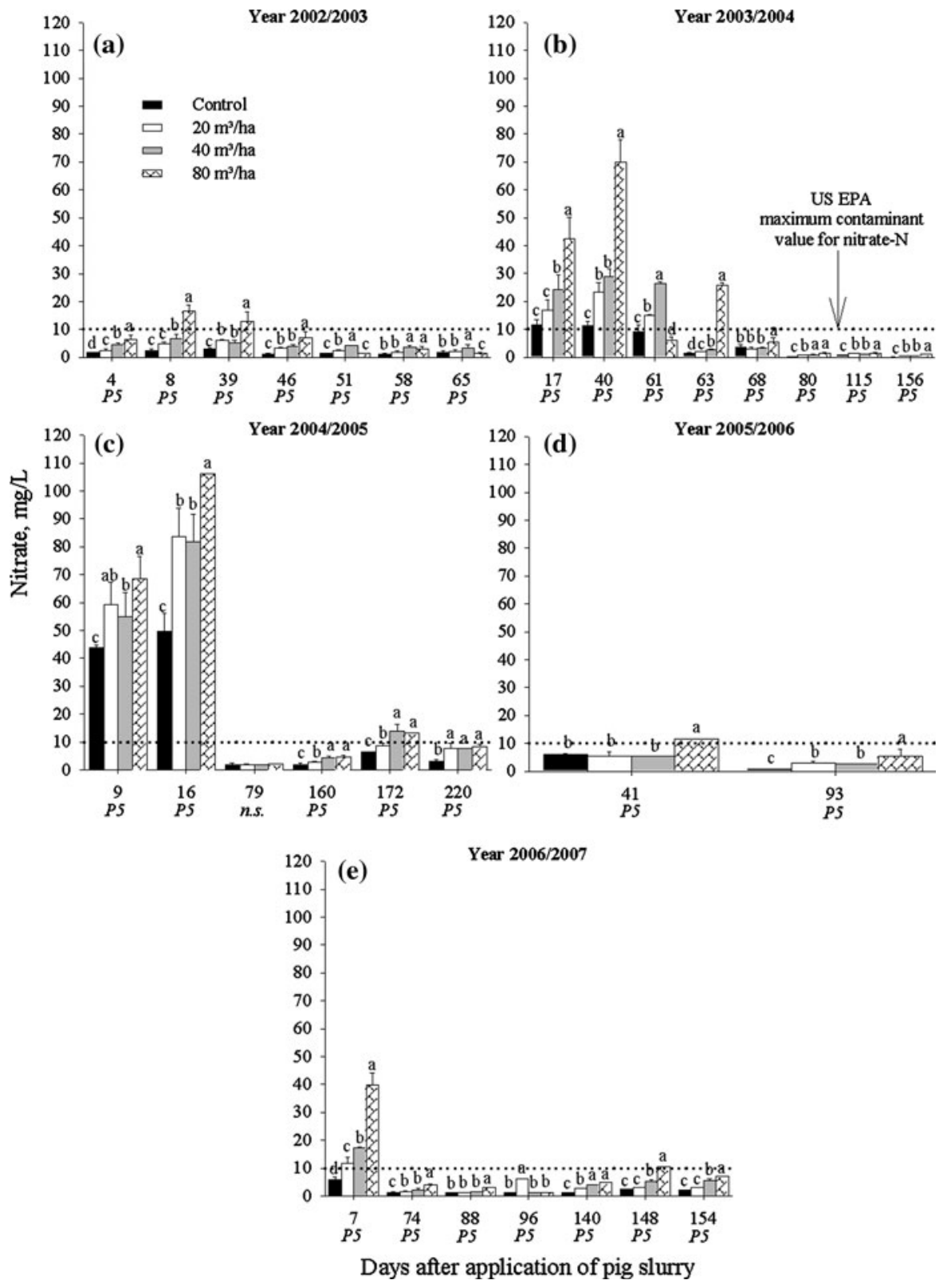

Fig. 4 Nitrate $\left(\mathrm{N}^{-\mathrm{NO}_{3}}{ }^{-}\right)$transfer through leaching in the following crops: black beans (2002/2003) (a), maize (2003/ 2004) (b), maize (2004/2005) (c), black beans (2005/2006) (d) and maize (2006/2007) (e), in areas under repeated pig slurry applications and no-tillage (bars standard errors). Significance

and $80 \mathrm{~m}^{3} \mathrm{ha}^{-1}$ doses, respectively. Thus, deducting these percentages of loss through volatilization, the total $\mathrm{N}$ amounts effectively applied to the soil within the period under evaluation were 457, 903 and $1,758 \mathrm{~kg} \mathrm{ha}^{-1}$, with 20,40 and $80 \mathrm{~m}^{3} \mathrm{ha}^{-1}$ pig slurry levels are based ANOVA testing system for differences between treatment means. Letters designate differences between treatments means, identified by Tukey-Kramer multiple comparison tests, while n.s. denotes statistical similarity amongst means

doses. However, despite the large amount of $\mathrm{N}$ applied to the soil through pig slurry, the amount of $\mathrm{NH}_{4}{ }^{+}-\mathrm{N}$ transferred by leaching during the 5 years period can be regarded as very small because from the total $\mathrm{N}$ applied to the soil throughout the experiment through pig slurry 
Fig. 5 Phosphorus extracted by the transfer of $\mathrm{HCl} 0.11 \mathrm{~mol} \mathrm{~L}^{-1}$ through leaching in the following crops: black beans (2002/ 2003) (a), maize (2003/ 2004) (b), maize (2004/ 2005) (c), black beans (2005/2006) (d) and maize (2006/2007) (e), in areas under repeated pig slurry applications and no-tillage (bars standard errors). Significance levels are based ANOVA testing system for differences between treatment means. Letters designate differences between treatments means, identified by Tukey-Kramer multiple comparison tests, while n.s. denotes statistical similarity amongst means
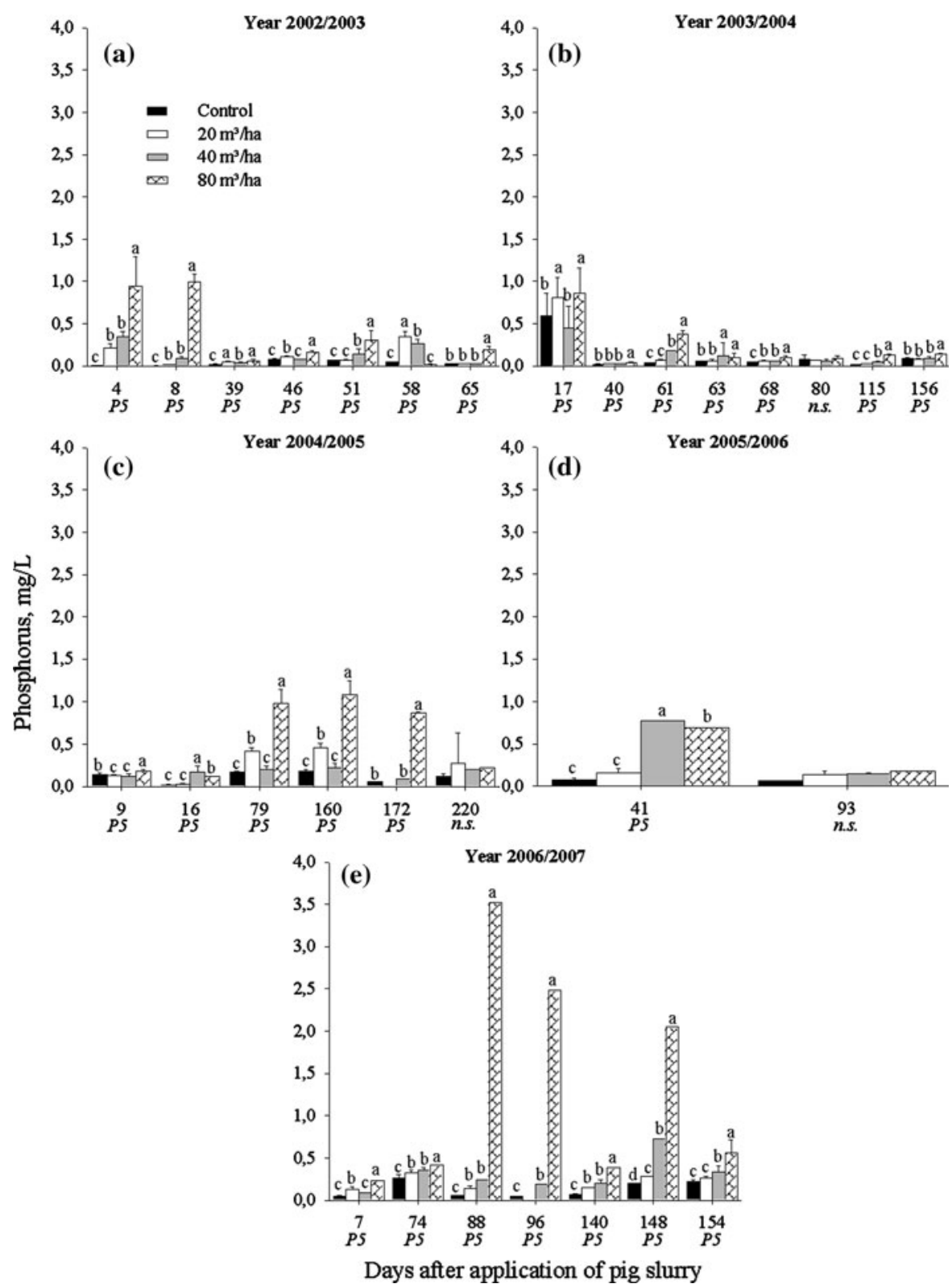

(Tables 1 and 2), 1.11, 0.96 and $0.71 \mathrm{~kg} \mathrm{ha}^{-1}$ of ammonium were transferred at the doses of 20, 40 and $80 \mathrm{~m}^{3} \mathrm{ha}^{-1}$ of pig slurry, which represents, on average, $0.11,0.04$ and $0.006 \%$ of the total $\mathrm{N}$ applied in each dose (Table 2), respectively.

The $\mathrm{NH}_{4}{ }^{+}-\mathrm{N}$ transfer by leaching did not show correlation with the pig slurry doses used in any of the 5 years assessed (Table 3 ). Nevertheless, the amount of $\mathrm{NH}_{4}{ }^{+}-\mathrm{N}$ transferred during the 5 years studied showed correlation with the leachate solution volume accumulated during the aforementioned period. The ammonium levels in the leachate solution were determined only in the first events subsequent to slurry applications. The reason is that after slurry application, the $\mathrm{NH}_{4}{ }^{+}-\mathrm{N}$ is rapidly converted into $\mathrm{NO}_{3}{ }^{-} \mathrm{N}$ in the soil (Diez et al. 2001; Payet et al. 2009). That was reflected in the results obtained in this study, in which the $\mathrm{NH}_{4}{ }^{+}-\mathrm{N}$ transfers were significant in only three of the events assessed at 4 and 8 days after pig slurry application to the common bean crop in the 
2002/2003 crop season (Fig. 3a), and at 9 days after pig slurry application to the maize crop in the 2004/2005 crop season (Fig. 3c), in treatments with the application of 20,40 and $80 \mathrm{~m}^{3} \mathrm{ha}^{-1}$ of pig slurry. Such results corroborate those obtained by Aita et al. (2007), who, in a Ultisol soil, similar to that used for this study, in a no-tillage system with pig slurry application on the soil surface, found that 20 days after the application of $130 \mathrm{~kg} \mathrm{ha}^{-1}$ of $\mathrm{NH}_{4}{ }^{+}-\mathrm{N}$ in the form of pig slurry, practically all the $\mathrm{NH}_{4}{ }^{+}-\mathrm{N}$ had been oxidized, being converted into the $\mathrm{NO}_{3}{ }^{-}-\mathrm{N}$ form.

The amounts of $\mathrm{NO}_{3}{ }^{-}-\mathrm{N}$ transferred by leaching over the 5 years were $22.5,24.6$ and $19.4 \mathrm{~kg} \mathrm{ha}^{-1}$, with 20,40 and $80 \mathrm{~m}^{3} \mathrm{ha}^{-1}$ pig slurry applications, respectively. Compared to the amounts of $\mathrm{N}$ applied to the soil, such transfers can be considered small since they represent, on average, 3.43, 1.97 and $0.71 \%$ of the total $\mathrm{N}$ applied at each dose, respectively. In the same experiment, Basso et al. (2005) reported that, from 2000 to 2002, the amount of mineral $\mathrm{N}$ transferred by leaching tended to increase with the doses of pig slurry applied, but it was small, with an average of 1.4, 0.7 and $2.1 \%$ of the total $\mathrm{N}$ applied being detected at the doses of 20,40 and $80 \mathrm{~m}^{3} \mathrm{ha}^{-1}$ of pig slurry, respectively. The amount of $\mathrm{N}$ transferred by leaching is associated with the dose of slurry applied and its $\mathrm{N}$ content. An example of this is the data obtained by Daudén et al. (2004) in an experiment with slurry applications equivalent to $275,356,462$ and $924 \mathrm{~kg} \mathrm{~N} \mathrm{ha}^{-1}$, in which the $\mathrm{NO}_{3}{ }^{-}-\mathrm{N}$ transfers were $9.5,11.6,16.5$ and $33.9 \%$ of the total $\mathrm{N}$ applied by pig slurry, respectively.

The $\mathrm{NO}_{3}{ }^{-}-\mathrm{N}$ transfer by leaching showed correlation with the pig slurry doses that were applied on the soil only in the first 2 years assessed (2002/2003 and 2003/2004) (Table 3). However, the amount of $\mathrm{NO}_{3}{ }^{-}-\mathrm{N}$ transferred by leaching showed correlation with the amount of $\mathrm{N}$ applied to the soil in the form of slurry over the 5 years and with the accumulated volume of leachate solution over the years (Table 3). A similar correlation was observed by Daudén et al. (2004) after a single application on the soil of 50, 100 and $200 \mathrm{Mg} \mathrm{ha}^{-1}$ of pig slurry. These results suggest that the addition of high amounts of $\mathrm{N}$ to the soil in the form pig slurry increases $\mathrm{NO}_{3}{ }^{-}-\mathrm{N}$ transfer by leaching and can consequently contaminate surface and underground waters (Bergström and Kirchmann 2006; Payet et al. 2009). According to Randall and Mulla (2001), the largest $\mathrm{N}$ transfers by leaching occur when there is above normal rainfall and especially in periods in which crops have slow growth rates and, thus, further low uptake of mineral $\mathrm{N}$ forms in the soil, like $\mathrm{NO}_{3}{ }^{-}-\mathrm{N}$.

In Brazil, the upper limit of $\mathrm{NO}_{3}{ }^{-}-\mathrm{N}$ in water intended for human consumption is $10 \mathrm{mg} \mathrm{L}^{-1}$ (CONAMA 2005). The highest $\mathrm{NO}_{3}{ }^{-}-\mathrm{N}$ concentrations in the leachate solution were observed in the maize crop (2004/2005), to which $80 \mathrm{~m}^{3} \mathrm{ha}^{-1}$ pig slurry was applied, representing an addition of $\mathrm{N}$ equivalent to $296 \mathrm{~kg} \mathrm{ha}^{-1}$ to the soil. For example, on the 16th day after slurry application, the $\mathrm{NO}_{3}{ }^{-}-\mathrm{N}$ concentration in the leachate solution was $106.1 \mathrm{mg} \mathrm{L}^{-1}$ (Fig. 4c). A similar behavior was observed during the maize crop for the 2003/2004 crop season (Fig. 4b), when the equivalent of $320 \mathrm{~kg} \mathrm{ha}^{-1}$ was applied at the dose of $80 \mathrm{~m}^{3} \mathrm{ha}^{-1}$ (Table 1). In addition, the greatest concentrations of $\mathrm{NO}_{3}{ }^{-}-\mathrm{N}$ in the leachate solution were observed in the first events after the application of the slurry, as observed by Daudén et al. (2004). That occurs because the $\mathrm{NH}_{4}{ }^{+}-\mathrm{N}$ present in the slurry in the soil is rapidly oxidized into $\mathrm{NO}_{3}{ }^{-}-\mathrm{N}$ (Smith et al. 2007) which, if not taken up by plants, can be easily transferred into the soil profile, especially in sandy soils, like the one used for this study.

\section{Phosphorus transfer}

During the 5 years assessed and the 12 pig slurry applications, the total $\mathrm{P}$ amounts applied were 508, 1,016 and $2,032 \mathrm{~kg} \mathrm{ha}^{-1}$, at doses of 20,40 and $80 \mathrm{~m}^{3} \mathrm{ha}^{-1}$ of pig slurry. Over this period, the transfers of $\mathrm{P}$ extracted by $\mathrm{HCl} 0.11 \mathrm{~mol} \mathrm{~L}^{-1}$ were, on average, $0.01,0.01$ and $0.02 \%$ of the total $\mathrm{P}$ applied, which corresponds to $0.31,0.35$ and $0.59 \mathrm{~kg} \mathrm{ha}^{-1}$ for the doses of 20, 40 and $80 \mathrm{~m}^{3} \mathrm{ha}^{-1}$ of slurry, respectively (Table 2). Despite the large amounts of $\mathrm{P}$ applied to the soil during the assessment period, the amounts of $\mathrm{P}$ extracted by $\mathrm{HCl}$ $0.11 \mathrm{~mol} \mathrm{~L}^{-1}$ transferred by leaching were very small. In addition, the data obtained in this study are similar to those obtained by Bergström and Kirchmann (2006), who, in an experiment with undisturbed soil columns, determined $\mathrm{P}$ transfers by leaching of $42.0 \mathrm{~g} \mathrm{ha}^{-1}$, on average, with application equivalent to $160 \mathrm{~kg} \mathrm{P} \mathrm{ha}^{-1}$ in the form of pig slurry in an assessment period of 3 years.

The transfers of $\mathrm{HCl} 0.11 \mathrm{~mol} \mathrm{~L}^{-1}$ extracted P by leaching were higher for treatments with the application 


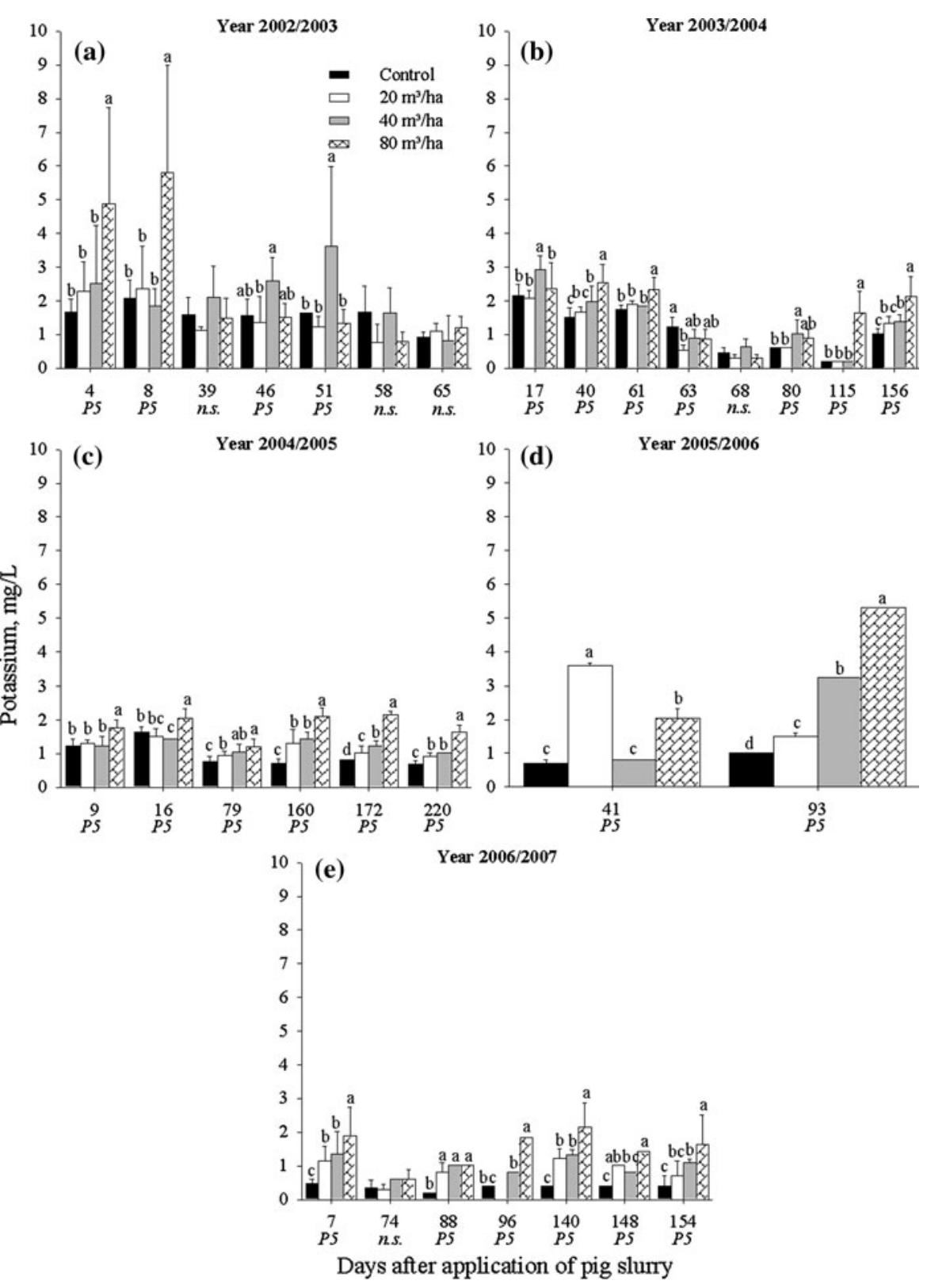

Fig. 6 Potassium extracted by the transfer of $\mathrm{HCl}$ $0.11 \mathrm{~mol} \mathrm{~L}^{-1}$ transfer through leaching in the following crops: black beans (2002/2003) (a), maize (2003/2004) (b), maize (2004/2005) (c), black beans (2005/2006) (d) and maize (2006/ 2007) (e), in areas under repeated pig slurry applications and

of greater doses of pig slurry, showing a close correlation between $\mathrm{P}$ transfers and the amounts applied with the slurry (Table 3). Moreover, repeated slurry applications over the years tend to cause saturation, by $\mathrm{P}$, of part of the most avid functional groups of reactive soil no-tillage (bars standard errors). Significance levels are based ANOVA testing system for differences between treatment means. Letters designate differences between treatments means, identified by Tukey-Kramer multiple comparison tests, while n.s. denotes statistical similarity amongst means

particles located in the surface layer of the soil. This means that, over time and with repeated pig slurry applications, the probability of $\mathrm{P}$ migration in the soil profile should increase. However, the leached amounts up to a depth of $0.60 \mathrm{~m}$ over the 5 years of slurry 
application, proved to be of little significance. That can be gathered from the equations presented in Table 3, i.e., in such situations, with repeated slurry applications, if slurry containing $100 \mathrm{~kg} \mathrm{ha}^{-1}$ of $\mathrm{P}$ is applied in treatments with doses of 20 and $80 \mathrm{~m}^{3} \mathrm{ha}^{-1}$ of slurry, $\mathrm{P}$ transfer by leaching will be 0.135 and $0.338 \mathrm{~kg} \mathrm{ha}^{-1}$, respectively. The fact that $P$ transfers by leaching were related to the volume of the leachate solution over the 5 years of slurry applications adds force to the aforementioned conclusion (Table 3).

The highest $\mathrm{P}$ concentration available in the leachate solution was observed at the dose of $80 \mathrm{~m}^{3} \mathrm{ha}^{-1}$ at 88 days after application in the maize crop (2006/2007), reaching a value of $3.52 \mathrm{mg} \mathrm{L}^{-1}$ (Fig. 5e). Moreover, in all the crops assessed, there were events in which $\mathrm{P}$ contents in the leachate solution were higher than $0.15 \mathrm{mg} \mathrm{L}^{-1}$, reaching the maximum concentration allowed for class 3 water (water that can be used for human consumption after treatment), according to the CONAMA (2005). That indicates that repeated slurry applications increase $P$ transfer by leaching, contaminating underground waters (Sharpley et al. 1994; Correll 1998; Pautler and Sims 2000; Smith et al. 2001; Ajmone-Marsan et al. 2006; Gatiboni et al. 2007).

\section{Potassium transfer}

From 2002 to $2007,216,432$ and $864 \mathrm{~kg} \mathrm{~K} \mathrm{ha}^{-1}$ were applied on the soil with the application of doses of 20 , 40 and $80 \mathrm{~m}^{3} \mathrm{ha}^{-1}$ of slurry, respectively. The available $\mathrm{K}$ amounts (extracted by $\mathrm{HCl} 0.11 \mathrm{~mol} \mathrm{~L}^{-1}$ ) transferred by leaching during the period evaluated were $2.32,3.68,3.74$ and $5.24 \mathrm{~kg} \mathrm{~K} \mathrm{ha}^{-1}$ for doses of $0,20,40$ and $80 \mathrm{~m}^{3} \mathrm{ha}^{-1}$ of slurry, respectively. These amounts of available $\mathrm{K}$ transferred by leaching are relatively small, as they are, on average, equivalent to $0.65,0.33$ and $0.34 \%$ of the total $\mathrm{K}$ applied with 20 , 40 and $80 \mathrm{~m}^{3} \mathrm{ha}^{-1}$ of pig slurry, respectively. These results indicate that transfers of available $\mathrm{K}$ by leaching go up with increasing doses of slurry applied and, therefore, with greater addition of $\mathrm{K}$. This becomes clear through analysis of Table 3, which shows the relationship between the doses and amounts of $\mathrm{K}$ applied, and the transfers of available $\mathrm{K}$ by leaching. Moreover, it is important to highlight that transfers of available $\mathrm{K}$ show a correlation with the volume of solution transferred by leaching throughout the years assessed (Table 3).
The highest concentrations of available $\mathrm{K}$ in the leachate solution were observed for the dose of $80 \mathrm{~m}^{3} \mathrm{ha}^{-1}$ of slurry for the common bean crop (2002/2003), reaching a value of $5.81 \mathrm{mg} \mathrm{L}^{-1}$ at 8 days after slurry application (Fig. 6a). These results corroborate those obtained by Ernani et al. (2007) after the application of increasing doses of $\mathrm{K}$, in the form of $\mathrm{KCl}$, both in an Alfisol soil and a Cambisol soil. These authors found that with the increase in the amount of $\mathrm{K}$ applied, there was a greater concentration in the leachate solution. However, results showed that $\mathrm{K}$ losses by leaching were relatively small, not exceeding $4 \%$ of the total amount applied.

In relative terms, $\mathrm{K}$ transfers were greater than those of $\mathrm{NH}_{4}{ }^{+}-\mathrm{N}$ and the $\mathrm{P}$ extracted by $\mathrm{HCl}$ $0.11 \mathrm{~mol} \mathrm{~L}^{-1}$, but lower than those of $\mathrm{NO}_{3}{ }^{-}-\mathrm{N}$, results which are similar to the ones obtained by Piovesan et al. (2009). Regarding the total amounts of $\mathrm{N}, \mathrm{P}$ and $\mathrm{K}$ applied with 20,40 and $80 \mathrm{~m}^{3} \mathrm{ha}^{-1}$ of slurry in the 12 applications and over the 5 years assessed, transfers by leaching were $0.11,0.04$ and $0.006 \%$ of $\mathrm{NH}_{4}{ }^{+}-\mathrm{N}, 3.43,1.97,0.71 \%$ of $\mathrm{NO}_{3}{ }^{-} \mathrm{N}$, $0.01,0.01$ and $0.02 \%$ of $\mathrm{P}$ extracted by $\mathrm{HCl}$ $0.11 \mathrm{~mol} \mathrm{~L}^{-1}$, and $0.65,0.33$ and $0.34 \%$ of available $\mathrm{K}$, respectively. In quantitative terms, transfers were 1.11, 0.96 and $0.71 \mathrm{~kg} \mathrm{ha}^{-1}$ of $\mathrm{NH}_{4}{ }^{+}-\mathrm{N} ; 22.5,24.6$ and $19.4 \mathrm{~kg} \mathrm{ha}^{-1}$ of $\mathrm{NO}_{3}{ }^{-}-\mathrm{N} ; \quad 0.31,0.35$ and $0.59 \mathrm{~kg} \mathrm{ha}^{-1}$ of $\mathrm{P}$; and $3.68,3.74$ and $5.24 \mathrm{~kg} \mathrm{ha}^{-1}$ of $\mathrm{K}$, for doses of 20,40 and $80 \mathrm{~m}^{3} \mathrm{ha}^{-1}$ of slurry, respectively. These results indicate that special attention should be given to the $\mathrm{NO}_{3}{ }^{-}-\mathrm{N}$ applied to soil through pig slurry since, in addition to the large amount of $\mathrm{N}$ applied with the slurry, the low $\mathrm{NO}_{3}{ }^{-}-\mathrm{N}$ adsorption affinity with reactive particles in the soil can increase the amounts transferred by leaching, contaminating underground waters.

\section{Conclusion}

Repeated applications of pig slurry in a no-tillage system in sandy soil led to the transfer of elements through the leachate solution according to the sequence: nitrate $>$ potassium $>$ ammonium $>$ phosphorus. The transfers of these elements were positively related to the increased volume of leachate solution over the years, in addition to the nutrient amounts added by the pig slurry applied over the 60-month period. Results from this study showed that 
leaching of total $\mathrm{N}$ went up with increasing applications of pig slurry. In contrast, leaching of $\mathrm{P}$ and $\mathrm{K}$ were small in all treatments that received application of pig slurry. This suggests that to regulate animal manure application rates based on $\mathrm{P}$ inputs is questionable for sandy soils, at least if environmental concerns related to $\mathrm{P}$ leaching are the motivation.

Acknowledgments The authors thank the CNPq, CAPES and FAPERGS for financial support.

\section{References}

Adeli A, Varco JJ, Rowe DE (2003) Swine effluent irrigation rate and timing effects on bermudagrass growth, nitrogen and phosphorus utilization and residual soil nitrogen. J Environ Qual 32:681-686

Adeli A, Bolster CH, Rowe DE, Mclaughlin MR, Brink GE (2008) Effect of long-term swine effluent application on selected soil properties. Soil Sci 173:223-235

Aita C, Port O, Giacomini SJ (2006) Dinâmica do nitrogênio no solo e produção de fitomassa por plantas de cobertura no outono/inverno com o uso de dejetos de suínos. $\mathrm{R}$ Bras $\mathrm{Ci}$ Solo 30:901-910

Aita C, Giacomini SJ, Hübner AP (2007) Nitrificação do nitrogênio amoniacal de dejetos líquidos de suínos em solo sob sistema plantio direto. Pesq Agropec Bras 42:95-102

Ajmone-Marsan F, Côte D, Simard RR (2006) Phosphorus transformations under reduction in long-term manured soils. Plant Soil 282:239-250

Allen BL, Mallarino AR (2008) Effect of liquid swine manure rate, incorporation, and timing of rainfall on phosphorus loss with surface runoff. J Environ Qual 37:125-137

Barrow NJ, Bolland MDA, Allen DG (1998) Effect of previous additions of superphosphate on sorption of phosphate. Aust J Soil Res 36:359-372

Basso CJ, Ceretta CA, Pavinato PS, Silveira MJ (2004) Perdas de nitrogênio de dejeto líquido de suínos por volatilização de amônia. Ci Rural 34:1773-1778

Basso CJ, Ceretta CA, Durigon R, Poletto N, Girotto E (2005) Dejeto líquido de suínos: II-Perdas de nitrogênio e fósforo por percolação no solo sob plantio direto. Ci Rural 35: 1305-1312

Bergström L, Kirchmann H (2006) Leaching and crop uptake of nitrogen and phosphorus from pig slurry as affected by different application rates. J Environ Qual 35:1803-1811

Cassol PC, Gianello C, Costa VEU (2001) Frações de fósforo em estrumes e sua eficiência como adubo fosfatado. R Bras Ci Solo 25:635-644

Ceretta CA, Durigon R, Basso CJ, Barcellos LAR, Vieira FCB (2003) Características químicas de solo sob aplicação de esterco líquido de suínos em pastagem natural. Pesq Agropec Bras 38:729-735

Ceretta CA, Basso CJ, Vieira FCB, Herbes MG, Moreira ICL, Berwanger AL (2005) Dejeto líquido de suínos: I-perdas de nitrogênio e fósforo na solução escoada na superfície do solo, sob plantio direto. Ci Rural 35:1296-1304
Ceretta CA, Lorensini F, Brunetto G, Girotto E, Gatiboni LC, Lourenzi CR, Tiecher TL, Conti L, Trentin G, Miotto A (2010a) Frações de fósforo no solo após sucessivas aplicações de dejetos de suínos em plantio direto. Pesq Agropec Bras 45:593-602

Ceretta CA, Girotto E, Lourenzi CR, Trentin G, Vieira RCB, Brunetto G (2010b) Nutrient transfer by runoff under no tillage in a soil treated with successive applications of pig slurry. Agric Ecosyst Environ 139:689-699

Chardon WJ, Aalderink GH, van der Salm C (2007) Phosphorus leaching from cow manure patches on soil columns. J Environ Qual 36:17-22

CONAMA-Conselho Nacional do Meio Ambiente. 2005. Resolução CONAMA $\mathrm{N}^{\circ}$ 357. Available at: http://www.crq4.org. br/downloads/resolucao357.pdf. (verified 20 April 2007), CONAMA, Brasília

Correll DL (1998) The role of phosphorus in the eutrophication of receivingwater a review. J Environ Qual 27:261-266

Daudén A, Quílez D, Vera MV (2004) Pig slurry application and irrigation effects on nitrate leaching in Mediterranean soil lysimeters. J Environ Qual 33:2290-2295

Diez JA, Torre AI, Cartagena MC, Carballo M, Vallejo A, Muñoz MJ (2001) Evaluation of the application of pig slurry to an experimental crop using agronomic and ecotoxicological approaches. J Environ Qual 30:2165-21172

Edwards RD, Daniel CT (1993) Runoff quality impacts of swine manure applied to fescue plots. Am Soc Agric Eng 36:81-86

Ernani PR, Bayer C, Almeida JA, Cassol PC (2007) Mobilidade vertical de cátions influenciada pelo método de aplicação de cloreto de potássio em solos com carga variável. R Bras Ci Solo 31:393-402

Ferreira DF (2008) SISVAR: um programa para análises e ensino de estatística. Rev Symp 6:36-41

Gatiboni LC, Rheinheimer DS, Kaminski J, Flores JPC (2007) Biodisponibilidade de formas de fósforo acumuladas em solo sob sistema plantio direto. R Bras Ci Solo 31:691-699

Gatiboni LC, Brunetto G, Kaminski J, Rheinheimer DS, Ceretta CA, Basso CJ (2008) Formas de fósforo no solo após sucessivas adições de dejeto líquido de suínos em pastagem natural. R Bras Ci Solo 32:1753-1761

Girotto E, Ceretta CA, Brunetto G, Rheinheimer DS, Silva LS, Lourenzi CR, Lorensini F, Vieira RCB, Schmatz R (2010) Acúmulo e formas de cobre e zinco no solo após aplicações sucessivas de dejeto líquido de suínos. R Bras Ci Solo 34:955-965

Hooda PS, Truesdale VW, Edwards AC, Withers PJA, Aitken MN, Miller A, Rendell AR (2001) Manuring and fertilization effects on phosphorus accumulation in soils and potential environmental implications. Adv Environ Res 5:13-21

Johnson KN, Kleinman PJA, Beegle DB, Elliott HA, Saporito LS (2011) Effect of dairy manure slurry application in a notill system on phosphorus runoff. Nutr Cycl Agroecosyst 90:201-212

Kayser M, Isselstein J (2005) Potassium cycling and losses in grassland systems: a review. Grass For Sci 60:213-224

Laboski CAM, Lamb JA (2003) Changes in soil test phosphorus concentration after application of manure or fertilizer. Soil Sci Soc Am J 67:544-554

Lloveras J, Arán M, Villar P, Ballesta A, Arcaya A, Vilanova X, Delgado I, Munõz F (2004) Effect of swine slurry on alfalfa 
production and on tissue and soil nutrient concentration. Agron J 96:986-991

Logan TJ, Eckert DJ, Beak DG (1994) Tillage, crop and climatic effects on runoff and tile drainage losses of nitrate and four herbicides. Soil Tillage Res 30:75-103

Loria ER, Sawyer JE (2005) Extractable soil phosphorus and inorganic nitrogen following application of raw and anaerobically digested swine manure. Agron J 97:879-885

Malhi SS, Johnston AM, Gill KS, Pennock DJ (2004) Landscape position effects on the recovery of $15 \mathrm{~N}$-labelled urea applied to wheat on two soils in Saskatchewan, Canada. Nutr Cycl Agroecosyst 68:85-93

Murphy J, Riley JP (1962) A modified single solution method for the determination of phosphate in natural waters. Anal Chim Acta 27:31-36

Pautler MC, Sims JT (2000) Relationships between soil test phosphorus soluble phosphorus and phosphorus saturation in Delaware soils. Soil Sci Soc Am J 64:765-773

Payet N, Findeling A, Chopart JL, Feder F, Nicolini E, Macary HS, Vauclin M (2009) Modelling the fate of nitrogen following pig slurry application on a tropical cropped acid soil on the Island of Réunion (France). Agric Ecosyst Environ 134:218-233

Piovesan RP, Favaretto N, Pauletti V, Motta ACV, Reissmann CB (2009) Perdas de nutrientes via subsuperfície em colunas de solo sob fertilização mineral e orgânica. R Bras Ci Solo 33:757-766

Randall GW, Mulla DJ (2001) Nitrate nitrogen in surface waters as influenced by climatic conditions and agricultural practices. J Environ Qual 30:337-344

Sharpley AN, Chapra SC, Wedepohl R, Sims JT, Daniel TC, Reddy KR (1994) Managing agricultural phosphorus for protection of surface waters: issues and options. J Environ Qual 23:437-451

Smith KA, Jackson DR, Withers PJA (2001) Nutrient losses by surface run-off following the application of organic manure to arable land: phosphorus. Environ Pollut 112:53-60

Smith DR, Owens PR, Leytem AB, Warne-Muende EA (2007) Applications as impacted by time to first runoff event. Environ Pollut 147:131-137

Staff Soil Survey (2006) Soil taxonomy: a basic system of soil classification for making and interpreting soil surveys, 2nd edn. US Government Printing Office, Washington DC $333 \mathrm{p}$

Tedesco MJ, Gianello C, Bissani CA, Bohnen H, Volkweiss SJ (1995) Análises de solo, planta e outros materiais. (Boletim técnico, 5), Porto Alegre, 2nd. edn. Univ. Federal do Rio Grande do Sul, Press 